\title{
Consumer Social Responsibility in Dutch Law
}

\author{
A Case Study on the Role of Consumers in Energy Transition
}

Katalin Cseres*

\section{Abstract}

As our economies continue to focus on growth, competition and maximisation of consumer choice, the global increase in consumption takes vast environmental and social costs and cause irreversible harm to our climate and environment. The urgency of reducing human footprint and to diminish one of the root causes of a declining climate and environment is irrefutable. In the shift that globally has to take place, a decentralised energy system relying on more distributed generation, energy storage and a more active involvement of consumers form a crucial component of renewable energy solutions. The move from a highly centralised to a more decentralised power system involves an increasing amount of small-scale (intermittent) generation from renewable energy which is located closer to the point of final consumption. In order to steer consumption towards sustainability national governments and supranational organisations have adopted policies and corresponding legislation that address who make socially responsible choices when they receive the 'right' amount of information. By relying on insights from modern consumption theories with contributions from sociology, this article questions the effectiveness and legitimacy of these 'consumer-centred' policies and laws. First, the article argues that the single focus on individual consumer behaviour as a rational and utility maximising market actor fails to take into account the complexity of consumption, which is fundamentally influenced by social norms and its broader institutional setting. Although consumers are willing to consume more sustainably, they are often 'locked in by circumstances' and unable to engage in more sustainable consumption practices even if they want to. Second, by relying on evidence from sociological studies the article argues that individual consumers are not the most salient actors in support of sustainable consumption. Even though the urgency of the energy transition and the critical role consumers play in (un)sustainable energy consumption is acknowledged in both the EU and its Member States, their laws and policies remain grounded on goals of economic growth with competitive economies, the sovereignty of consumer choice and wealth maximisation, instead of aiming at slower economic growth or even degrowth, reducing overall resource use and consumption levels and introducing radically different ways of consumption.

* Katalin Cseres is Associate Professor of Law, Amsterdam Centre for European Law \& Governance (ACELG), University of Amsterdam.

Third, the role of law is underlined as a social institution both as a constraint on the autonomous acts of consumption, dictating the normative frameworks within which the role of consumer is defined, and as a facilitator which consumers might also employ, in order to determine for themselves particular normative parameters within which consumption can occur.

The Netherlands, which serves as a case study in this article, has reached important milestones in its energy transition policy since 2013. Still, it remains strongly focused on economic rationality and market competitiveness. Even though various models of consumer participation exist and local consumer energy initiatives are flourishing and are recognised as key actors in the energy transition, they remain embedded in institutional, structural and behavioural settings where consumers still face challenging sociocultural barriers to sustainable practices.

In light of these legal, political and social complexity of energy transition, the article offers a critical analysis of the current Dutch law in its broader legal context of EU law in order to answer the question what the role of (energy) law is in steering consumers towards sustainable energy consumption.

Keywords: consumer, energy transition, social responsibility, Dutch law, EU law

\section{Introduction}

As our economies continue to focus on growth, competition and maximisation of consumer choice, the global increase in consumption takes vast environmental and social costs and cause irreversible harm to our climate and environment. ${ }^{1}$ Especially Europe's consumption contributes more to environmental degradation than other regions across the globe. In 2018, European households were responsible for $26 \%$ of direct energy consumption in Europe by using electricity and gas for, among others, space heating, water heating and the use of appliances. ${ }^{2}$ At the same time, Europe's prospects of reaching its environmental policy objectives for 2030

1. European Environment Agency, Growth without economic growth, report, 2020. https://www.eea.europa.eu/publications/growthwithout-economic-growth

2. Energy consumption and use by households, https://ec.europa.eu/ eurostat/web/products-eurostat-news/-/DDN-20200626-1. 
and 2050 remain poor. ${ }^{3}$ The urgency of reducing human footprint and thus to diminish one of the root causes of a declining climate and environment is irrefutable. ${ }^{4}$ The immediate transformation of the global energy system with vast commitment to renewable energy and increasing energy efficiency is, therefore, of vital relevance for modern societies that are highly dependent on electricity supply. ${ }^{5}$ Acknowledging that unsustainable energy consumption is one of the main contributing factors to current sustainability crisis ${ }^{6}$ socially responsible consumer behaviour is seen as key to address the ecological and social problems caused by the negative impact of dominating consumption patterns in affluent societies. ${ }^{7}$ In the shift that globally has to take place, a decentralised energy system relying on more distributed generation, energy storage and a more active involvement of consumers form a crucial component of renewable energy solutions. The move from a highly centralised to a more decentralised power system involves an increasing amount of small-scale (intermittent) generation from renewable energy which is located closer to the point of final consumption. ${ }^{8}$ Consequently, consumers ${ }^{9}$ have an essential role to play in achieving the flexibility necessary to adapt the electricity system to variable and distributed sustainable electricity generation and, hence, mitigate climate change.

In an attempt to steer consumption towards sustainability national governments and supranational organisations have adopted policies and corresponding legislation that address individual consumers as rational and active choice-makers who make socially responsible choices when they receive the 'right' amount of information. ${ }^{10}$ Accordingly, legislators and policymakers have placed the responsibility for the energy transition on consumers. ${ }^{11}$ For example, the European Commission's Clean

3. Several of Europe's environmental footprints exceed the planetary boundaries, EEA/FOEN Joint Report, 2020.

4. IPCC special report on the impacts of global warming of $1.5^{\circ} \mathrm{C}$. www.ipcc.ch/site/assets/uploads/sites/2/2019/06/

SR15_Chapter3_Low_Res.pdf; U. Schrader and J. Thøgersen, ‘Putting Sustainable Consumption into Practice', 34 Journal of Consumer Policy 3-8 (2011), https://doi.org/10.1007/s10603-011-9154-9.

5. www.irena.org/-/media/Files/IRENA/Agency/Publication/2019/Jun/ IRENA_G20_climate_sustainability_2019.pdf.

6. Two-thirds of greenhouse gas emissions originate from the energy sector. Globally, the use of energy represents by far the largest source of greenhouse gas emissions from human activities. In Europe the energy processes are the largest emitter of greenhouse gases, being responsible for $78 \%$ of total EU emissions in 2015. www.eea.europa.eu/signals/ signals-2017/articles/energy-and-climate-change.

7. Schrader and Thøgersen, above n. 4 .

8. Decentralised generation is directly connected to the distribution grid and thereby located closer to the loads that it serves.

9. In this article consumer will be used for individual and final consumers acting for purposes outside their trade, profession and business.

10. E. Heiskanen and S. Laakso, 'Editing Out Unsustainability from Consumption: From Information Provision to Nudging and Social Practice Theory', in O. Mont (ed.) A Research Agenda for Sustainable Consumption Governance (2019).

11. O. Mont, 'Introduction to a Research Agenda for Sustainable Consumption Governance', in O. Mont (ed.) A Research Agenda for Sustainable Consumption Governance (2019). Heiskanen and Laakso, above n. 10.
Energy Package ${ }^{12}$ places consumers at the centre of the EU's energy policy and implements a broad range of initiatives to make consumers an active part of the clean energy transition. ${ }^{13}$ Similarly, EU member states have also been drafting and implementing ambitious energy transition and climate change laws and policies. The Netherlands, which serves as a case study in this article, has reached important milestones in its energy transition policy since 2013. Its proposal for a new comprehensive Electricity and Gas Act of July $2020^{14}$ is the first legislation with clear aims to stimulate the energy transition through facilitating the active participation of endusers towards more sustainable energy consumption and self-sufficiency. ${ }^{15}$ Despite these legal and policy developments and the positive attitude of consumers across Europe to achieve a more sustainable energy system, progress has been slow. In the Netherlands the share of renewable energy is the lowest among the twenty-eight EU countries. ${ }^{16}$ As $\mathrm{CO} 2$ emissions remain steady ${ }^{17}$ and the progress towards renewable energy sources is limited, ${ }^{18}$ the Netherlands is furthest away from its renewable energy targets. ${ }^{19}$

By relying on insights from modern consumption theories with contributions from sociology, this article questions the effectiveness and legitimacy of these 'consumer-centred' policies and laws. First, the article argues that the single focus on individual consumer behaviour

12. Directive (EU) $2019 / 944$ of the European Parliament and of the Council of 5 June 2019 on common rules for the internal market for electricity and amending Directive 2012/27/EU (OJ L 158, 14 June 2019, p. 125).

13. Commission Communication of 25 February 2015, 'A Framework Strategy for a Resilient Energy Union with a Forward-Looking Climate Change Policy', Commission Communication of 15 July 2015, 'Delivering a New Deal for Energy Consumers'; New Consumer Agenda Strengthening consumer resilience for sustainable recovery, $\operatorname{COM}(2020) 696$ final.

14. Conceptvoorstel van wet houdende regels over energiemarkten en energiesystemen, Conceptvoorstel Wet (versie internetconsultatie 17 december 2020), Memorie van toelichting wetsvoorstel Energiewet, publieke versie 17 december, both available: www.internetconsultatie.nl/energiewet.

15. Memorie van toelichting wetsvoorstel Energiewet, publieke versie 17 december, pp. 7-8.

16. SDGs in the Netherlands, Status Report 2020. CBS. www.cbs.nl/en-gb/ publication/2020/27/sdgs-in-the-netherlands-status-report-2020.

17. Greenhouse gas emissions (IPCC) per capita and greenhouse gas intensity of the economy are trending down towards the targets. While the trends are towards the targets of the SDG, the Netherlands does not perform well relative to other countries. Remarkably, in per capita greenhouse gas emissions the Netherlands ranks 24th out of 28. CBS, above n. 16; www.nrc.nl/nieuws/2020/01/24/nederland-is-in-euminst-duurzaam-a3988037.

18. In 2019, renewable energy consumption in the Netherlands grew by $16 \%$ relative to the previous year. More than half of this increase was due to increased consumption of biomass, particularly co-firing in power plants and in the form of biodiesel and biogasoline. In addition, solar power consumption rose substantially. This is shown by the latest figures released by Statistics Netherlands (CBS). www.cbs.nl/en-gb/news/ 2020/22/renewable-energy-consumption-up-by-16-percent; www.cbs.nl/en-gb/figures/detail/83109ENG; www.cbs.nl/en-gb/ publication/2020/27/sdgs-in-the-netherlands-status-report-2020.

19. Renewable energy in the EU in 2018, Share of renewable energy in the EU up to $18.0 \%$, Twelve Member States have reached a share equal to or above their 2020 target, https://ec.europa.eu/eurostat/documents/ 2995521/10335438/8-23012020-AP-EN.pdf/

292cf2e5-8870-4525-7ad7-188864ba0c29. 
as a rational and utility maximising market actor fails to take into account the complexity of consumption, which is fundamentally influenced by social norms and its broader institutional setting. Although consumers are willing to consume more sustainably, they are often 'locked in by circumstances' and unable to engage in more sustainable consumption practices even if they want to. ${ }^{20}$

Second, by relying on evidence from sociological studies ${ }^{21}$ the article argues that individual consumers are not the most salient actors in support of sustainable consumption. ${ }^{22}$ The evidence highlights the need for governments to lead the shift to sustainability instead of creating 'consumer scapegoatism'. ${ }^{23}$ Even though the urgency of the energy transition and the critical role consumers play in (un)sustainable energy consumption is acknowledged in both the $\mathrm{EU}^{24}$ and its member states, ${ }^{25}$ their laws and policies remain grounded on goals of economic growth with competitive economies, the sovereignty of consumer choice and wealth maximisation, instead of aiming at slower economic growth or even degrowth, reducing overall resource use and consumption levels and introducing radically different ways of consumption. By focusing on the individual albeit active, responsible consumer who cares enough about the environment to make the right choices, governments adopt a narrow and simplistic model ${ }^{26}$ and approach sustainable consumption merely 'at arm's length'. ${ }^{27}$

Besides a more complex understanding of the concerned consumer taking into account social interactions, environmental and other institutional frameworks, topdown action by governments is vital and behavioural change must occur at the collective level.

Third, the role of law is underlined as a social institution both as a constraint on the autonomous acts of consumption, dictating the normative frameworks within which the role of consumer is defined, and as a facilita-

20. C. Sanne, ‘Willing Consumers - Or Locked-In? Policies for a Sustainable Consumption', 42 Ecological Economics 273 (2002).

21. E. Shove and G. Walker 'What Is Energy For? Social Practice and Energy Demand', 31(5) Theory, Culture \& Society 41-58 (2014).

22. The term 'sustainable consumption' is an umbrella term for a diverse set of approaches and conceptualisations with three main focuses: consuming more efficiently, consuming differently or consuming less.

23. L. Akenji, 'Consumer Scapegoatism and Limits to Green Consumerism', 63 Journal of Cleaner Production 13-23 (2014) Web.

24. The European Green Deal is a 'new growth strategy for the EU that aims to transform the EU into a fair and prosperous society, improving the quality of life of current and future generations, with a modern, resource-efficient and competitive economy [emphasis added] where there are no net emissions of greenhouse gases in 2050 and where economic growth is decoupled from resource use'. The European Green Deal, $\operatorname{COM}(2019) 640$ final.

25. The transition towards a CO2-free electricity system is 'owned by everyone'. This is crucial to maintain and improve social support. The transition is a joint task of citizens, market parties, public authorities, civic organisations and the world of knowledge and science. Citizens can actively participate in new projects. Proposal for key points of the Climate Agreement 10 July 2018

26. E. Shove, 'Beyond the ABC: Climate Change Policy and Theories of Social Change', 42(6) Environment and Planning A 1273-85 (2010).

27. K. Hobson, 'Sustainable Consumption in the United Kingdom: The 'Responsible' Consumer and Government at 'Arm's Length', 13(2) Journal of Environment \& Development 121-39 (2004). tor which consumers might also employ, in order to determine for themselves particular normative parameters within which consumption can occur. Accordingly, law has a vital role by having a transformative effect upon the act of consumption and the role of the consumer. $^{28}$

The Netherlands serves as an important case study to illustrate the above arguments. The Netherlands has pursued a strongly market-oriented energy policy relying on economic considerations for decades without an institutionally supported renewable energy policy or support for consumer participation. Despite the important milestones it realised in its energy transition policy since 2013 and even though strengthening the market position of consumers is one of the core pillars of the new Energy Act, ${ }^{29}$ it remains strongly focused on economic rationality and market competitiveness. Even though various models of consumer participation exist and local consumer energy initiatives are flourishing and are recognised as key actors in the energy transition, they remain embedded in institutional, structural and behavioural settings where consumers still face challenging sociocultural barriers to sustainable practices. The role of law in creating and sustaining such a broader institutional framework is crucial. ${ }^{30}$

In light of these legal, political and social complexity of energy transition, the article offers a critical analysis of the current Dutch law in its broader legal context of EU law in order to answer the question what the role of (energy) law is in steering consumers towards sustainable energy consumption.

In order to answer this question, the article will first assess the complex processes and sociotechnical dimension of energy transition and locate the role of consumers and their alleged responsibility in this process. It then turns to how (EU and Dutch) law currently conceptualises consumer responsibility.

By relying on insights from social practices theory it critically evaluates these concepts and the role law could play in shaping consumer responsibility and thus steer consumers towards sustainability. Finally, against the background of the general EU law framework it assesses the Dutch energy (transition) law and policy against the insights gained from social practices theory and the role of consumer social responsibility. The article closes with conclusions.

28. M. Everson and C. Joerges, 'Consumer Citizenship in Postnational Constellations?', EUI Law Working Paper 2006/47:9

29. Memorie van toelichting wetsvoorstel Energiewet, pubieke versie 17 december, See Pillars IV and V of the Concept Act, p. 5.

30. Shove and Walker, above n. 21. 


\section{Consumers and the Energy Transition}

\subsection{The Energy Transition}

Today energy systems are among the largest human enterprises and they form the heart of the technological arrangements around which contemporary industrial economies are organised. Sustainable energy is at the centre of the United Nations' 2030 Agenda for Sustainable Development and it underpins the achievement of most, if not all, Sustainable Development Goals. ${ }^{31}$ Therefore, transforming energy systems involve changes that affect not only energy technologies and prices but also the broader social and economic assemblages that are built around energy production and consumption. ${ }^{32}$ They are socio-technological systems that involve not only machines, pipes and devices but also the humans who design technologies, develop and manage practices, and who use and consume energy. ${ }^{33}$ The transition to sustainable energy is a pathway towards transforming the global energy sector by reducing greenhouse gas emissions and by substituting fossil energy consumption with renewable energy consumption in order to mitigate the effects of climate change. It is a change in the primary form of energy consumption of a given society as well as a complex and multifaceted, social, economic and political process. ${ }^{34}$ The current energy transition is profoundly influenced by the characteristics of renewable energy sources that are different from those of the conventional technologies, such as increased dependency on weather and fewer possibilities to control production. Renewable energy has the advantage of being carbon neutral during electricity generation; however, its integration in current electricity systems poses additional challenges. The physical nature of renewable energy sources means that the generation of energy becomes more variable, less predictable and decentralised compared to traditional generation. ${ }^{35}$ One solution to this challenge focuses on integrating flexibilities that consumers can offer for improved matching of the variability or intermittency of renewable energy sources with electricity demand. ${ }^{36}$ It is in this context that consumers have an essential role to play in achieving the flexibility necessary to adapt the electricity system to variable and distributed renewable

31. https://unece.org/fileadmin/DAM/energy/se/pdfs/CSE/Publications/ Final_Report_PathwaysToSE.pdf, p. vii.

32. A. Clark Miller, I. Alastair lles \& C.F. Jones, 'The Social Dimensions of Energy Transitions', Science as Culture 135-48, at 135 (2013).

33. Miller, lles \& Jones, above n. 32.

34. A. Proka, M. Hisschemöller \& D. Loorbach, 'Transition without Conflict? Renewable Energy Initiatives in the Dutch Energy Transition', 10 Sustainability 1721 (2018). D. Loorbach, 'Transition Management for Sustainable Development: A Prescriptive, Complexity-based Governance Framework', 23 Governance 161-83 (2010)

35. L. Diestelmeier, Unlocking Flexibility with Law: Developing a Legal Framework for Smart Electricity Systems (2019), at 9.

36. Dynamic prices could function as a financial incentive for consumers to adjust their demand. Demand flexibility thus becomes of essential value with an increasing amount of RES. electricity generation and thus contribute to the transition to a sustainable energy system.

\subsection{Consumers' Role in the Energy Transition}

The role and behaviour of consumers, both as participants in sustainable energy consumption and production, is an important aspect of the energy transformation. Today the availability of low-cost technological devices enables consumers to use technologies, such as rooftop solar panels, batteries and smart metres and directly control and manage their individual consumption patterns. This, arguably, provides strong incentives for efficient energy use if combined with time-dependent electricity prices. ${ }^{37}$ Internet-based metering and trading solutions enable even consumer households to generate and store electricity. Consumers can sell generated electricity, offer flexibilities in demand and provide balancing services for maintaining system operation which becomes increasingly valuable for integrating variable renewable energy sources. ${ }^{38}$ In this way, consumers become prosumers. ${ }^{39}$

Hence, the current technological setting of the market enables consumers to manage their consumption and thus reduce their energy bills while participating actively in the shift from fossil fuels to renewable sources. Consumers' capacity to drive sustainable consumption is, however, subject to various constraints. First, despite the fact that households often express strong support for sustainable energy consumption, for example, by their willingness to pay for green electricity, these attitudes are seldom reflected in actual behaviour. ${ }^{40}$ As an illustration, even though Dutch citizens show a positive attitude to making the energy supply more sustainable, surveys showed that sustainability is relatively low on Dutch citizens' agenda. ${ }^{41}$ Second, in the current elec-

37. Smart energy technology can automatically follow price fluctuations and offer accurate and frequent information to consumers on their consumption and it enables them to adjust their behaviour accordingly to the price signals. S.G. Rodrigo, 'Changing the Energy Model: Step Back on the Europe 2050 Strategy?', 25(2) European Energy and Environmental Law Review 65-72, at 66-67 (2016).

38. L. Diestelmeier, 'Changing Power: Shifting the Role of Electricity Consumers with Blockchain Technology - Policy Implications for EU Electricity Law', 128 Energy Policy 189-96 (2019).

39. Prosumers are consumers who start generating electricity primarily for their own needs. See Directive 2018/2001 on 'renewable self-consumer'. The term 'prosumer' originally coined by Alvin Toffler (1980) refers to the development of the individual's participation in markets from being a passive consumer to an active participant in production, maintenance and repair of consumer goods. Prosumption has been perceived to have the potential to achieve the functions that consumption performs for the individual, but with reduced environmental impact. S. Eden, 'Blurring the Boundaries: Prosumption, Circularity and Online Sustainable Consumption Through Freecycle', 17(2) Journal of Consumer Culture 265-85 (2017).

40. C. Berglund and S. Matti, 'Citizen and Consumer: The Dual Role of Individuals in Environmental Policy', 15(4) Environmental Politics 553 (2006). A. Hansla, A. Gamble, A. Juliusson \& T. Gärling, 'Psychological Determinants of Attitude and Willingness to Pay for Green Electricity', 36 Energy Policy 768-774 (2008). C. Dalhammar, 'It Is Never Too Late to Give Up, Or Is It? Revisiting Policies for Sustainable Consumption', in O. Mont (ed.), A Research Agenda for Sustainable Consumption Governance, Chapter 9 (2019) 137-155.

41. Dutch citizens also estimate the share of renewable energy to be higher than it is in reality. Pubieksmonitor Klimaat en Energie, Motivaction, 
tricity sector the possibility to offer demand flexibility depending on dynamic prices is mostly directed towards large consumers, and potential flexibilities of small consumers located at the distribution grid level remain ineffective. ${ }^{42}$ This has been especially so in the Netherlands, where energy policies and subsidies generally aim at large corporate projects with high profitability. Citizen projects with their typically modest revenue models fit much less into this policy. ${ }^{43}$ Third, an important finding of sociological research on sustainable consumption is that individual consumers' decision making is influenced by various institutional factors such as social institutions, consumer culture or collective behaviour. ${ }^{44}$ Consumption is socially embedded and is shaped by existing (unsustainable) institutional settings and infrastructures. $^{45}$ Due to these legal, social and market boundaries, consumers are often 'locked in by circumstances' and unable to engage in more sustainable consumption practices even if they want to. ${ }^{46}$ Against this background, the question arises how law, as a social institution, and public policies account for the institutional, social and other influences on individuals' behaviour. This is the question the next section turns to.

\subsection{The Role of Policies and Legislation to Support Active and Responsible Consumer in the Energy Transition}

From a legal-policy perspective, the energy transition involves the actions governments are taking in order to steer away from fossil fuels and to move towards a clean energy future. These include various policies, administrative and economic measures that aim to influence the deployment of renewables and energy efficiency improvements. For example, tax benefits or waivers to capital grants measures rewarding heat or power generation, self-consumption or energy efficiency codes. ${ }^{47}$

Law plays a crucial role in the electricity sector by establishing the rules for the use of the electricity system. Even though legal rules depend on the technical setting of the electricity supply system and also on broader policy goals related to economic, social or environmental objectives, law shapes the social context of consumer behaviour by assigning rights and responsibilities to various actors. ${ }^{48}$ More importantly, law can constrain or facilitate consumption, enable or disable certain

2019, pp. 7-8. https://www.rijksoverheid.nl/documenten/rapporten/ 2020/01/16/publieksmonitor-klimaat-en-energie-2019-motivaction; Integrated National Energy and Climate Plan 2021-2030, Netherlands, 2019, p. 12.

42. Diestelmeier, above n. 38, at 132

43. S. Akerboom and F. van Tulder, 'Consumer (Co-)Ownership in Renewables in the Netherlands', in J. Lowitzsch (ed.), Energy Transition (2019).

44. Shove, above n. 26 .

45. Heiskanen and Laakso, above n. 10, at 157. The Swedish Environmental Protection Agency, Sustainable Consumption, Research and Policies, Report (2005), at 58.

46. Sanne, above n. 20, at 273.

47. K. Daszkiewicz, 'Policy and Regulation of Energy Transition', in M. Hafner and S. Tagliapietra (eds.), The Geopolitics of the Global Energy Transition. Lecture Notes in Energy, vol. 73 (2020).

48. Diestelmeier, above n. 38 , at 24 consumer choices. Consumers now act within and interact with the supranational legal order of the EU and national laws that can create and sustain infrastructures that structure the way we consume. ${ }^{49}$

The current legal framework of energy markets was designed for a centrally organised sector and not a decentralised system. Therefore, the legal framework of the energy sector defines actors and subsequent rights and responsibilities along a centralised and 'top-down' electricity supply chain. This setting stands in contrast with a decentralised renewable energy-based system, which aims at incentivising and coordinating the demand side as a flexible part of the electricity supply chain. ${ }^{50}$

As a result of the increasing variable energy supply connected to the distribution grid, the current legal setting needs to change. The change is underway: as will be discussed below, EU and national energy policies embrace strategies that are aimed at facilitating self-generation, self-consumption and sale of electricity to the grid and urge businesses and consumers to make alternative choices for more renewable energy. These policies address consumers as active and responsible agents $^{51}$ who are given the 'power and mandate' to lead the shift to sustainable energy. ${ }^{52}$ Although it is undeniable that individuals play an important role in the change towards sustainability, there is increasing evidence that shows that individual consumers are not the most salient actors in support of sustainable consumption. ${ }^{53}$

Against this background, and acknowledging the fact that legislation can affect the social context that shapes human interactions and behaviour, the next section will first analyse how current (EU and Dutch) law conceptualises the consumer and consumer responsibility and how these laws comply with sustainable consumption theories.

\section{Consumer Responsibility}

The laws and policies that regulate the position and behaviour of consumers are inherently market based. ${ }^{54}$

49. Everson and Joerges, above n. 28.

50. The legal framework of the electricity sector establishes roles and responsibilities for the users of the network, who are referred to as system users (producers and consumers), the system operators for different voltage levels (transmission and distribution systems), and coordinating and supervising bodies at national and supranational level. These actors are producers, transmission- and distribution system operators, suppliers and consumers. Diestelmeier, above n. 35, at 8.

51. O. Mont, E. Heiskanen, K. Power, et al., Improving Nordic Policymaking by Dispelling Myths on Sustainable Consumption (2013), http:// norden.diva-portal.org/smash/get/diva2:702825/FULLTEXT01.pdf, at 34. See also definition of active customer in Art. 2. Directive 2019/944.

52. See Arts. 1 and 3 of Directive 2019/944: Art. 3 Competitive, consumercentred, flexible and non-discriminatory electricity markets. Mont, above n. 11, at 2 .

53. A. Horta, 'Energy Consumption as Part of Social Practices: The Alternative Approach of Practice Theory', in J. Debra, J. Davidson \& M. Gross (eds.), Oxford Handbook of Energy and Society (2018), at 1-22.

54. Micklitz argues that 'consumer law follows the market rationale' and that it is intrinsically tied to the market and its relevance for the society 
'The deeper structures of consumer law' have a strong 'consumerist bias'. 55 Consumer laws support consumption and they are embedded in market economies that support consumers' 'free choice' and 'consumer sovereignty' and are dominated by the paradigm of economic growth. Consumer choice also stands central in the EU integration project, where consumers have the key advantage to enjoy the growth of consumer choice in an enlarged internal market. ${ }^{56}$ This is in stark contrast with theories of (strong) sustainable consumption that are based on the idea of consuming less, consuming differently and consuming more efficiently. ${ }^{57}$

Against this background, how can legal rules promote sustainable consumption and formulate provisions that enable consumers' 'felt obligation' ${ }^{58}$ to consume less and consume in different ways?

In order to answer the question how law can support consumer responsibility and through what means consumers become responsible, the next sections will analyse how EU and Dutch law currently conceptualises the consumer and consumer responsibility.

\subsection{The Normative Concept of the Consumer in EU and Dutch Law}

The central premise of consumer laws has been the protection of the 'weaker party' by regulating contractual aspects of the relationship between consumers and traders with the goal of promoting fair and efficient markets for the benefit of consumers. The foundation of consumer law is anchored in the idea that the consumer lacks bargaining power vis-à-vis traders and can be subject to exploitation and market abuses. However, EU consumer law has developed with the aim of reducing barriers to intra-EU trade and completing the Single Market. Hence, EU consumer law has a strong internal 'market-promoting objective' and the role of the consumer is to support market integration and ultimately economic growth. This instrumentalist perception is also mirrored in the way the consumer is conceived in EU law: a self-confident market actor who contributes to the well-functioning of markets. ${ }^{59}$

Correspondingly, EU law relies on the benchmark of the 'average' consumer who is a well-informed, reasona-

we are living in H.-W. Micklitz, 'Squaring the Circle? Reconciling Consumer Law and the Circular Economy', 8(6) Journal of European Consumer and Market Law 229-37, at 230 (2019).

55. T. Wilhelmsson, 'Consumer Law and the Environment: From Consumer to Citizen', 21 Journal of Consumer Policy 45-70, at 49 (1998).

56. Wilhelmsson, above n. 55, at 49.

57. The term 'sustainable consumption' is an umbrella term for various approaches and conceptualisations, but three streams can be distinguished: consuming more efficiently, consuming differently or consuming less. Mont, above n. 11, at 137-55. S. Lorek and P.J. Vergragt, 'Sustainable Consumption as a Systemic Challenge: Inter- and Transdisciplinary Research and Research Questions', in L.A. Reisch, J. Thøgersen (eds.,) Handbook of Research on Sustainable Consumption (2015).

58. M.G. Luchs and R.A. Miller, 'Consumer Responsibility for Sustainable Consumption', in L. Reisch and J. Thøgersen (eds.), Handbook of Research on Sustainable Consumption (2015)

59. C.U. Schmid, 'The Instrumentalist Conception of the Acquis Communautaire in Consumer Law and Its Implications on a European Contract Law Code', 1 European Review of Contract Law 211-27 (2005). ble and circumspect market actor. ${ }^{60}$ According to the CJEU's jurisprudence, the consumer is able to use information and participate actively in the market by making informed choices. ${ }^{61}$

This instrumentalist link between the consumer and the internal market has also been the underlying premise in EU energy law that was adopted from the end of the 1990s. ${ }^{62}$ The normative concept of the consumer in regulated (energy) markets has historically been based on the neoclassical model of the consumer. Under this model, consumers behave in ways that maximise utility subject to a specific budget constraint, respond in predictable ways to changes in price and other relevant variables, have stable and consistent preferences; engage in optimal search activity; select the lowest price and highest quality products including by switching suppliers when it is optimal to do so; and have certain abilities when it comes to processing information. On the basis of this concept, behavioural change will be induced by policies that intensify competition, constrain the ability of existing suppliers with significant market power, increase quality or facilitate innovation. ${ }^{63}$

In Dutch law we see a similar conceptualisation of the consumer. The 2017 Coalition Agreement of the then Dutch government set out an ambitious energy policy, but it did not present a policy concerning sustainable consumption or how consumer policy could contribute to this development. ${ }^{64}$ In 2018 the Minister of Economic Affairs had formulated the most recent Consumer Agenda of the then Dutch government. The Agenda set out a policy that was based on the strong position of the consumer vis-à-vis suppliers and as a policy that contributes to competitive markets, freedom of choice and good quality products and services. ${ }^{65}$

60. The current definition of the normative concept is based on Gut Springheide where the Court explained that 'an average consumer, [who] is reasonably well informed and reasonably observant and circumspect' C-210/96 Gut Springenheide GmbH and Rudolf Tusky v. Oberkreisdirektor des Kreises Steinfurt - Amt für Lebensmittelüberwachung, ECLI:EU:C:1998:369, paras. 31 and 32.

61. The ECJ placed a great deal of confidence in consumers' ability to process information and therefore it has given preference to rules that require information disclosure as part of intervention in the market. Directive 2005/29 on Unfair commercial practices defines the average consumer as a reasonably well-informed and reasonably observant and circumspect person, taking into account social, cultural and linguistic factors, as interpreted by the Court of Justice. Recital 18 of Directive 2005/29/EC of the European Parliament and of the Council of 11 May 2005 concerning unfair business-to-consumer commercial practices in the internal market [2005 OJ L 149/22].

62. K. Cseres, 'The Active Energy Consumer in EU Law', 9(2) European Journal of Risk Regulation 227-44 (2018).

63. C. Decker, 'Concepts of the Consumer in Competition, Regulatory and Consumer Protection Policies', 13(1) Journal of Competition Law and Economics 151-84 (2017).

64. Confidence in the Future, 2017-2021 Coalition Agreement, People's Party for Freedom and Democracy (VVD), Christian Democratic Alliance (CDA), Democrats '66 (D66) and Christian Union (CU), www.government.nl/documents/publications/2017/10/10/coalitionagreement-confidence-in-the-future, p. 41. See also Integrated National Energy and Climate Plan, The Netherlands, 2021-2030. https:// ec.europa.eu/energy/sites/ener/files/documents/ nl_final_necp_main_en.pdf.

65. Kamerbrief: Consumentenagenda: houvast bij voortdurende verandering, Vergaderjaar 2018-2019, Kamerstukken 27 879, nr. 64. 
However, the Agenda does not mention any aspect of sustainable consumption. The Netherlands Authority for Consumers \& Markets had in the past year published a Guidance for the compatibility of sustainability agreements with the competition rules. This Guidance confirms the Dutch policy that considers sustainability as being one factor of a competitive market economy that stimulates more consumption by increasing the number of choices for consumers. ${ }^{66}$

From the consumer law jurisprudence of Dutch courts, a similar rational concept emerges. Dutch courts follow the model of the average consumer in EU law jurisprudence very closely ${ }^{67}$ and they emphasised that the average consumer benchmark is a legal standard and as such it requires limited investigation of whether and how consumers actually behave, for example, for assessing the transparency of the information. ${ }^{68}$ These consumerist legal approaches are based on a restricted approach concerning human behaviour and neglect the fact that consumers are influenced by more complex institutions than just economic rationality and external incentives. There is growing evidence that rules based on the paradigm of the active and rational consumer and relying on information provisions are ineffective and insufficient to empower consumers to steer markets towards sustainability. ${ }^{69}$ Even though the use of behavioural science and the tool of nudging has been considered cost-effective and useful, it has severe limitations in effectively sustainable consumption policy on a large scale. Using nudges to promote strong sustainable consumption on a large scale would require a massive administrative effort in the micromanagement of consumers' choice architectures. $^{70}$ Hence, its long-term outcomes prove to be

66. 'Sustainability and competition often go hand in hand. Just as competition can stimulate innovation in the form of new or improved products and processes, so can it stimulate sustainability too. Consumers often see sustainability as a quality improvement of a product, and the availability of sustainable products increases their options. Investments and improved production processes that use raw materials more efficiently not only offer businesses competitive advantages but are also in the interest of sustainability.' ACM, Draft Guidelines, Opportunities for sustainable agreements, 2020. www.acm.nl/sites/default/files/documents/ 2020-07/sustainability-agreements\%5B1\%5D.pdf.

67. J. Luzak, 'The Steady Creep of an Average Consumer as a Reference Consumer in the Assessment of the Transparent Provision of Mandatory Information', 5 Tijdschrift voor Consumentenrecht en handelspraktijken 270-71 (2020). V. Mak, 'De gemiddelde consument: Van fictie naar feit', 7 Ars Aequi, (2017) at 595. Dexia judgement Hoge Raad 5 juni 2009, NJ 2012/182. unfair commercial practices ECLI:NL:PHR: 2019:346, para. 4.15. See also Staatsloterij Hoge Raad 30 januari 2015, NJ 2015/301.

68. PHR 5 April 2019, ECLI:NL:PHR:2019:346, para. 4.15. Dutch courts draw comparisons with the CJEU's case law on UCTD provisions. The court of first instance in Rotterdam states that the requirement of drafting consumer information in plain and intelligible language may be found not only in Dutch provisions implementing the CRD but also in Arts. $4(2)$ and 5 UCTD, as transposed to Dutch law in Art. 6:238 para. 2 BW.

69. C.R. Le Quéré, R.M. Moriarty, R.M. Andrew, et al. 'Global Carbon Budget 2015', 7(2) Earth System Science Data 349-96 (2015). E.G. Hertwich, 'Consumption and the Rebound Effect: An Industrial Ecology Perspective', 9(1-2) Journal of Industrial Ecology 85-98 (2005).

70. M. Lehner, O. Mont \& E. Heiskanen, 'Nudging - A Promising Tool for Sustainable Consumption Behaviour?', 134 Journal of Cleaner Production 166-77 (2016). modest. ${ }^{71}$ Moreover, researchers argued that stronger steering is required than a mere 'nudge', 72 in the form of coercive legislation, restricting consumer choice and strong economic incentives, rather than encouragement and voluntariness. ${ }^{73}$

Additionally, the individualist focus of legislation has been criticised by sociological research of consumption that shifted the focus of the analysis from isolated individualised behaviour to socially shared practices. ${ }^{74}$

Viewed in this way, energy forms an ingredient of specific social practices and is considered as a social process: ${ }^{75}$ energy is being used not for its own sake but as part of, and in the course of, accomplishing social practices, such as cooking, heating, commuting to work or conducting meetings. This requires radically reframing contemporary approaches to energy policy and sustainability and shifting the analysis to investigate the actual context and processes of energy use in everyday life, for example, how energy-intensive habits become normalised and embedded in our everyday life and how a complex mix of institutional factors (instead of individual choices of consumers) influence energy demand. ${ }^{76}$ Hence, consumption forms part of a larger system of investments, production and trade and it is embedded in economic, cultural and institutional context. Accordingly, changing consumption requires changing the entire economic system, the infrastructures, the dominant culture and lifestyles, and rethink of institutions and their underlying governance. ${ }^{77}$ As long as consumer law and other fields of law remain focused on consumerism and assist infrastructures and human behaviour on this basis, they will not enable or support sustainable consumption. Changes have to take place in the 'social fabric of society', which requires systemic changes in the prevailing economic institutions and business models, regulations and infrastructure through top-down action from governments. ${ }^{78}$ Social practices theory directs the focus of analysis towards practices in which we consume and towards the way law approaches consumers and consumption. ${ }^{79}$ In this process law plays a role by creating and sustaining infrastructures that accommodate and create demand and contribute to fundamentally changing institutions, formal and informal rules that shape the behaviour of its actors.

Accordingly, behavioural change must occur at collective level and go beyond individualised approaches focused on prices and attitudes and, with households

71. O. Mont, M. Lehner \& E. Heiskanen, Nudging - A Tool for Sustainable Behaviour? (Report 6643) (2014). Heiskanen and Laakso, above n. 10, at $158-60$.

72. Dalhammar, above n. 40 , at 140 .

73. Mont, above n. 11, at 13.

74. T. Shatzki, The Site of the Social: A Philosophical Account of the Constitution of Social Life and Change (2002).

75. Horta, above n. 53

76. Ibid., at 32

77. Lorek and Vergragt, above n. 57, https://doi.org/ 10.4337/9781783471270.00008.

78. Dalhammar, above n. 40, at 140. Mont, Heiskanen, Power, et al., above n. 51, at 34 .

79. Y. van den Berg, 'Regulating Consumers: A Practice Approach to Sustainable Consumption' Paper On file with author. 
and communities as units of analysis, should consider energy use as a social process, for example, by supporting community projects, such as the local energy communities in the Netherlands. ${ }^{80}$

\subsection{Consumer (Social) Responsibility}

The above insights imply that a transformation from the consumer as a rational economic agent has to be shifted to the citizen who exhibits moral motivations and is concerned with the common good of the community. Consumers' moral-based responsibility points to a sense of responsibility concerning the collective consequences of everyday activities. ${ }^{81}$ In fact, as Shove has also argued this means that fundamental questions about the role of the state and the allocation of responsibility within sustainability policy have to be rediscussed. ${ }^{82}$ In this discussion, the concept of consumer citizenship can provide guidance on how to conceptualise and interpret consumer responsibility in sustainability policies and laws. Citizenship has always been a matter of balancing rights and responsibilities. Historically, republican citizenship focuses on the responsibilities of citizens to the collective. ${ }^{83}$ The consumer is an economic concept and consumers are defined as economic entities with ever greater depth and breadth of choice rather than individuals with broader sociocultural and moral issues. Citizens, on the contrary, are defined by their membership and responsibility towards a community, their collective obligations and their social, economic and political rights. ${ }^{84}$ The point here is that scholars have argued that individuals tend to pursue their own goals as consumers, but are more conscious about the impact of their choices to the community as citizens. ${ }^{85}$ This is an important insight for law and policymakers as they could take account of the fact that individuals do not always have the same preferences in their role as citizens and in their role as consumers and design instruments accordingly. In this way, consumer responsibility can be qualified by giving weight to the citizens' duties which is explicated with terms of responsibility. Consumers are made responsible through processes of responsibilisation and policymakers should implement sustainability initiatives that highlight how individuals, companies and governments can co-create responsibility that helps increase consumers' sense of their own responsibility. ${ }^{86}$ Thus

80. O. Mont and K. Power, 'The Role of Formal and Informal Forces in Shaping Consumption and Implications for a Sustainable Society. Part I', 2 Sustainability 2232-52 (2010). T. Jackson, Motivating Sustainable Consumption, Sustainable Development Research Network (2005), at 170.

81. Berglund and Matti, above n. 40, at 553, 556. Dalhammar, above n. 40. Heiskanen and Laakso, above n. 10.

82. Shove, above n. 26 , at 1283

83. A. Dobson, 'Environmental Citizenship: Towards Sustainable Development', 15 Sustainable Development 276-85 (2007).

84. S. Ranchordas, 'Citizens as Consumers in the Data Economy: The Case of Smart Cities', 7(4) Journal of European Consumer and Market Law 154-61, at 159 (2018).

85. Berglund and Matti, above n. 40, at 553.

86. M.G. Luchs, M. Phipps and H. Tim, 'Exploring consumer responsibility for sustainable consumption' 13 Journal of Marketing Management, at 1464. environmental issues such as energy transition depend on awareness of shared responsibility and on the extent to which they are endorsed by multiple social actors, the current legal and regulatory frameworks and the legitimisation of related arguments in various institutional and societal settings. ${ }^{87}$

The following sections will explore how the regulatory mechanisms of EU and Dutch law facilitate active consumer and how they co-create and implement such richer concepts of consumer responsibility concepts.

\section{EU Law and Policy on Energy Transition and the Consumer's Role in Energy Transition}

The electricity markets of the Netherlands form part of the EU internal energy market and as such they have gone through profound changes as a result of EU market liberalisation process from 1996 on. The Dutch electricity system and policies have been transformed by the various requirements of the EU Directives over the past two decades. ${ }^{88}$ As the EU's renewables and decarbonisation agenda has a significant impact on the Netherlands' electricity policy, this section will provide a brief analysis of current EU energy law and policy developments that shape the Netherlands' energy law and policy.

4.1 EU Law and Policy on Energy Transition The EU has developed an extensive legal framework for energy markets since the late 1990s. The First and Second energy package focused on liberalising the energy sector, ${ }^{89}$ while the Third Package further facilitated market opening and free customer choice. ${ }^{90}$

87. R. Shamir, 'The Age of Responsibilization: On Market-Embedded Morality', 37(1) Economy and Society 1-19 (2008).

88. The requirements of EU Directives combined with the EU's renewable electricity and energy targets continue to affect the organisation of the energy sector and its regulation in all EU member states. M.G. Pollitt, 'The European Single Market in Electricity: An Economic Assessment', 55 Review of Industrial Organization 63-87 (2019).

89. The first package started to open up national markets in order to accommodate the supply of energy first to large-scale, industrial endusers by 1 July 2004 and from 1 July 2004 to non-household customers, as well. Directive 96/92/EC of the European Parliament and of the Council of 19 December 1996 concerning common rules of the internal market in electricity, OJ L 27/20 and Directive 98/30/EC of the European Parliament and the Council of 22 June 1998 concerning common rules for the internal market in natural gas, OJ L 204/1. The Second Energy Directives opened up the energy market for all end-users, including households. Directive 2003/54/EC of the European Parliament and of the Council of 26 June 2003 concerning common rules for the internal market in electricity and Art. 2 (28) and 23 of the Directive 2003/55/EC of the European Parliament and the Council of 26 June 2003 concerning common rules for the internal market in natural gas and repealing Directive 98/30/EC, OJ L 176/57.

90. Directive 2009/72/EC of the European Parliament and of the Council of 13 July 2009 concerning common rules for the internal market in electricity and repealing Directive 2003/54/EC, OJ L 211/55 and Directive 2009/73/EC of the European Parliament and the Council of 
The regulatory instrument to facilitate consumer participation in energy markets through legal provisions has been employed in the EU's liberalisation agenda since the 1990s. Consumer benefit has been one of the main objectives of market opening, ${ }^{91}$ but at the same time, energy law provisions concerning the position of the consumer were based on competitive market theory and aimed at completing the internal energy market and strengthening competition. ${ }^{92}$ These rules focused on enabling customer choice and switching. ${ }^{93}$ The central idea of EU energy law was that the promotion of competition and freedom of choice for consumers would lead to improved efficiency among energy companies, which in turn results in qualitatively higher standards of service at more affordable energy prices. The energy consumer was seen as a driver of competition. ${ }^{94}$

Since the Lisbon Treaty the EU has introduced and reinforced long-term decarbonisation objectives, and a growing role for climate change in its energy policies. ${ }^{95}$ As a global actor in the energy transition, the EU has stepped up its efforts to become an energy-efficient, low-carbon economy and to reach the goal of the 2015 Paris Agreement. ${ }^{96}$ The EU made firm commitments to

13 July 2009 concerning common rules for the internal market in natural gas and repealing Directive 2003/55/EC, OJ L 211/94.

91. The purpose of liberalising the EU's electricity and gas sector was to ensure that EU consumers receive the full benefits of market opening in terms of lower domestic bills for electricity and gas through the introduction of competition and the freeing of all electricity and gas consumers to choose their supplier. Directive of the European Parliament and of the Council amending Directives 96/92/EC and 98/30/EC concerning common rules for internal market in electricity and natural gas. Brussel: European Commission. COM (2001) 125 final, p. 33.

92. N. Reich, 'Harmonisation of European Contract Law: With Special Emphasis on Consumer Law',1(1) China-EU Law Journal 55 (2011).

93. A. Johnston, 'Seeking the EU "Consumer" in Services of General Economic Interest', in D. Leczykiewicz and S. Weatherill (eds.), The Images of the Consumer in EU Law (1st ed) (2015), 112, 114

94. The consumer has always been at the centre of the liberalisation and (de)regulation of energy markets. However, her role changed over time. First, the consumer's role was based on her active search behaviour by looking for the cheapest energy supplier, which, in fact, functions as the way to steer markets towards more efficiency. The European directives that implemented the liberalisation focused on breaking up national markets, to promote fair competition between energy companies in the $\mathrm{EU}$ and to guarantee energy users the right to freely choose their suppliers. The underlying public interest of the Directives and regulations in the Third Energy Package was to safeguard affordability, reliability and safety and sustainability of the energy supply for energy consumers. Cseres, above n. 62

95. As the constitutional basis of EU energy law was only adopted in 2009 with the Lisbon Treaty, it was Art. 194 TFEU that codified the existing objectives and formed the legal basis for adopting legal instruments in the energy sector. K. Huhta, 'Anchoring the Energy Transition with Legal Certainty in EU Law', 27(4) Maastricht Journal of European and Comparative Law (2020) 27(4)425-444; M.A. Eyl-Mazzega and C. Mathie, 'The European Union and the Energy Transition', in M. Hafner and S. Tagliapietra (eds.), The Geopolitics of the Global Energy Transition. Lecture Notes in Energy, vol. 73 (2020).

96. When the Juncker Commission took office in 2014, a resilient energy union with a forward-looking climate policy was identified as one of the ten priorities of the new Commission. On 25 February 2015, the Commission adopted 'A Framework Strategy for a Resilient Energy Union with a Forward-Looking Climate Change Policy', also known as the Energy Union Strategy. The publication of this strategy created a new momentum to bring about the transition to a low-carbon, secure and competitive economy. The objective of the Energy Union is to provide all European Union (EU) consumers - households and businesses - with transform energy markets from a centralised and largely fossil-fuel based, highly monopolistic and vertically integrated system delivering electricity to passive consumers towards a more decentralised power system, which relies to a larger extent on small-scale generation from renewable energy sources requiring active participation of consumers by smarter demand response management of their own energy use and by becoming producers themselves.

It has set targets of using renewable energy sources already following the 1997 White Paper on renewable energy sources. ${ }^{97}$ The EU's targets of using renewable energy sources had to meet $12 \%$ of energy consumption and $22.1 \%$ of electricity consumption needs by 2010 , with indicative targets for each member state set out in Directive 2001/77/EC on renewable energy sources. However, the lack of progress towards achieving the 2010 targets led to the adoption of a more comprehensive legislative framework, the 'Renewable Energy Road Map' ${ }^{98}$ Here a mandatory target of using renewable energy sources was set to meet $20 \%$ of EU energy consumption needs by 2020, a mandatory target of $10 \%$ of transport fuel consumption coming from biofuels by 2020 and the creation of a new legislative framework. This new legal framework has taken shape with the adoption of the Renewable Energy Directive ${ }^{99}$ and the Energy Efficiency Directive ${ }^{100}$ in 2009 setting requirements of environmental and climate policy and formulating the idea that consumers need to be encouraged to be more efficient in their energy use. ${ }^{101}$

In 2015 the Commission adopted the Energy Union Strategy that laid out a pathway for transition to a deca-

secure, sustainable, competitive and affordable energy. The Energy Union has five dimensions: (i) security of supply, solidarity and trust; (ii) a fully integrated energy market; (iii) energy efficiency; (iv) decarbonisation of the economy; and $(v)$ research, innovation and competitiveness.

97. Communication from the Commission ENERGY FOR THE FUTURE: RENEWABLE SOURCES OF ENERGY, White Paper for a Community Strategy and Action Plan COM(97)599 final (26 November 1997), p. 25. In the White Paper the Commission has emphasised the importance and dissemination of consumer information on quality goods and services for renewable energies in such a way that customers can choose anywhere in the internal market the most appropriate European product and source at the least price.

98. Renewable energies in the 21st century: building a more sustainable future $(\operatorname{COM}(2006)$ 0848).

99. Directive 2009/28/EC of the European Parliament and the Council of 23 April 2009 on the promotion of the use of energy from renewable sources and amending and subsequently repealing Directives 2001/77/EC and 2003/30/EC, OJL 140/16 2009. The 2009 Renewable Energy Directive mapped out various mechanisms that member states can apply in order to reach their national targets, as well as sustainability criteria for biofuels. Provisions of the 2009 Renewable Energy Directive require member states to provide either priority or guaranteed access to the grid system for all renewable electricity production, big and small. Similar provisions are included in the 2009 Electricity Directive. The Energy Efficiency Directive introduces a similar requirement for small-scale and micro-combined heat and power and requires member states to encourage participation of demand response in wholesale and retail markets and, when necessary, to include aggregators.

100. Directive 2012/27/EU of the European Parliament and the Council of 25 October 2012 regarding energy efficiency, in amendment of Directives 2009/125/EC and 2010/30/EC and subsequently repealing Directives 2004/8/EC and 2006/32/EC, OJ ECL 3152012, pp. 1-56.

101. Rec 6 and 50 of Directive 2009/72/EC. 
rbonised energy sector that delivers sustainable, secure, competitive and affordable energy. In order to implement the objectives established in the Energy Union Strategy the EU Commission has proposed the Clean Energy for All Europeans package in 2016 for the internal electricity market ${ }^{102}$ and its legal entered into force as the Fourth Package in 2019. ${ }^{103}$ The Package encompasses eight legislative documents that facilitate a 'consumer-centred clean energy transition' and reform: the design and operation of the European Union's electricity market. One of the three main goals of the package is to realise a clean energy system through the active participation of consumers in energy markets. ${ }^{104}$ Likewise, in 2016, the Commission proposed a revised Renewable Energy Directive to ensure that the target of at least a $27 \%$ share of renewables in the total amount of energy consumed in the EU by 2030 is met. ${ }^{105}$ The revised Directive 2018/2001 ${ }^{106}$ establishes a new binding renewable energy target for the EU for 2030 of at least $32 \%$, with a clause for a possible upwards revision by 2023.

\subsection{The New Energy Market Design: A Legal \\ Framework for Active Consumer \\ Participation}

The EU's new energy market design of $2019^{107}$ puts the active participation of consumers at the centre of the energy transition. Instead of being dependent on a topdown energy model, consumers should actively manage their own consumption and even (co-)produce their own energy. The aim of the new EU rules is to make it easier for individuals to produce, store or sell their own energy, and strengthen consumer rights with more transparency on bills, and greater choice flexibility. ${ }^{108}$ The new market design as established by Directive 2019/944109 enables consumers' participation in all forms of demand

102. Proposal for a Directive on common rules for the internal market in electricity, COM (2016) 864 (Electricity Directive) and COM (2016) 861 (Electricity Regulation).

103. The Package documents can be grouped into three categories: proposals amending existing energy market legislation; proposals amending existing climate change legislation; and proposals for new measures. The Winter Package consists of legislative measures to facilitate the transition to a clean energy economy. The overall objectives of each proposed measure are briefly outlined in the Commission Communication 'Clean Energy for all Europeans', COM (2016) 860 final.

104. Commission Communication 'Clean Energy for all Europeans', COM (2016) 860 final.

105. https://ec.europa.eu/energy/en/topics/energy-strategy-and-energyunion/clean-energy-all-europeans.

106. In December 2018, the revised renewable energy directive 2018/2001/EU entered into force, as part of the Clean energy for all Europeans package, aimed at keeping the EU a global leader in renewables and, more broadly, helping the EU to meet its emissions reduction commitments under the Paris Agreement. The recast RED changes perspective and only sets an EU-wide target of $32 \%$ without any binding national targets.

107. https://ec.europa.eu/info/news/clean-energy-all-europeans-packagecompleted-good-consumers-good-growth-and-jobs-and-goodplanet-2019-may-22_en.

108. Commission communication, Clean Energy For All Europeans, COM/ 2016/0860 final.

109. Directive (EU) $2019 / 944$ of the European Parliament and of the Council of 5 June 2019 on common rules for the internal market for electricity and amending Directive 2012/27/EU (recast). response ${ }^{110}$ and allows them to adjust their consumption according to real-time price signals that reflect the value and cost of electricity or transportation in different time periods. With demand response, consumers can manage their consumption by using smart metres and thus using energy when the price is lower or selling energy when the price is higher. ${ }^{111}$

Directive 2019/944 not only reinforces existing energy consumer rights, but it also introduces new consumer rights. ${ }^{112}$ It lays down rules ensuring that consumers are able to freely choose suppliers (Art. 4) as well as change suppliers (Art. 12) or aggregators (Art. 13). Basic contractual rights were renewed in Article 10. Consumers are entitled to a dynamic price contract (Art. 11), that is, an electricity supply contract between a supplier and a final customer that reflects the price at the spot market. Article 14 gives consumers access, free of charge, to at least one certified price comparison tool and reinstates the obligation to provide consumers with frequent billing and billing information, which is correct, clear, concise and presented in a manner that facilitates comparison (Art. 18). Consumers can engage in demand response (Art. 17), self-generation and self-consumption (Art. 15 (b)). Moreover, Article 19 entitles every consumer to request a smart meter equipped with a minimum set of functionalities. Article 16 defines a framework for local energy communities which may engage in local energy generation, distribution, aggregation, storage, supply or energy efficiency services. The Directive also provides clarifications to pre-existing provisions on smart metres, single points of contacts, and rights to out-of-court settlement (Art. 26), universal service and vulnerable consumers.

Moreover, the revised Renewable Directive lays down the first EU legislation that aims to facilitate the involvement of household consumers in the deployment of renewable energy. The new Directive facilitates selfconsumers of renewables and their joint collectives. Even though self-consumers (prosumers) were already recognised in certain national renewable energy policies, they are addressed for the first time in EU law together with 'renewable energy communities'. Final consumers are now explicitly recognised (Arts. 2 and 21) to be able to generate, store and consume renewable energy and excess production and participate in the applicable support schemes. ${ }^{113}$ They can, moreover, participate in 'renewable energy communities' (Art. 22) without losing

110. Demand side response (DSR) is a voluntary reduction in electricity consumption taken from the grid by retail customers to react to an increase in the power price, or to some form of incentive payment.

111. Upon receiving a scarcity message, in particular a very high day-ahead price at a specified hour, they can decrease their consumption at that hour by disconnecting specific appliances, or use distributed generation equipment and/or rely on storage capabilities. To incentivise demand response, energy prices should vary between peak and off-peak periods according to supply and demand ('dynamic pricing'). CERRE Report, C. Crampes, C. Waddams, Empowering electricity consumers in retail and wholesale markets, 170309_CERRE_EnergyConsumers_Final, p. 23.

112. For the development of energy consumer rights see Cseres, above n. 62.

113. L. De Almeida, V. Capelli, N. Klausmann \& H. Van Soest, ‘Peer-to-peer Trading and Energy Community in the Electricity Market: Analysing the 
their consumer rights and obligations as end customers connected to the grid and without being faced with discriminatory or disproportionate procedures and charges. ${ }^{114}$

These new provisions aim at eliminating obstacles to consumers' active participation and facilitating their active engagement by providing them with comprehensive, transparent and detailed information concerning new forms of contracts and new technological possibilities. ${ }^{115}$

\subsection{A Sustainability-Centred EU Energy Law?}

However, EU energy law, including the Clean energy package, is still based on the idea that a well-functioning, competitive and integrated energy market is the best instrument to pursue the objectives of EU energy policy, including consumer activation. ${ }^{116}$

This regulatory approach well corresponds to the instrumentalist and market-building character of EU consumer law; the role of the consumer is to support the integration of energy markets. However, these objectives and the context in which EU internal market law has developed do not correspond to deep decarbonisation and is largely focusing on market integration, competition and supply security in order to serve the consumers' interests.

This EU law framework is dominated by the productivist model focusing on the strengthening of the internal market as a paradigm for extending consumer choice through unrestricted trade and intensified competition. ${ }^{117}$ Viewed in the context with other fields of EU law, such as state aid and competition law, this is an institutional setting strongly focusing on economic

Literature on Law and Regulation and Looking Ahead to Future Challenges', EUI RSC, 2021/35, Florence School of Regulation.

114. 'Renewable energy communities' are autonomous legal entities, based on open and voluntary participation, and effectively controlled by their shareholders or members (being natural persons, SMEs or local authorities), of which the primary purpose is to provide environmental, economic or social community benefits for its shareholders, members or for the local areas where it operates, rather than financial profits. Renewable energy communities can produce, consume (i.e. share within the community), store and sell renewable energy. In that regard they are entitled to access all suitable energy markets, directly or via an aggregator.

115. Huhta, above n. 95 , at 4 .

116. Ibid.

117. Reich discusses the 'initial "productivist concept" of the EEC Treaty and the problem of the promotion of consumer interests' in his chapter Economic Law, Consumer Interests and EU Integration in: H.-W. Micklitz, P. Rott \& N. Reich, Understanding EU Consumer Law (2009); E. Maitre-Ekern and C. Dalhammar 'Towards a Hierarchy of Consumption Behaviour in the Circular Economy', 26(3) Maastricht Journal of European and Comparative Law 409 (2019).

118. Promoting fair competition and easy access for different suppliers is of the utmost importance for member states in order to allow consumers to take full advantage of the opportunities of a liberalised internal market for electricity. Directive 2019/944 preamble point 12. Clean Energy for All Europeans package is based on the idea that a well-functioning, competitive and integrated energy market is the best instrument to achieve the objectives of EU energy policy, including consumer activation. K. Huhta, 'Unleashing Consumer Potential in the Energy Transition: A Reflection of the Transforming Role of the EU Consumer', 17(3) OGEL (2019), at 2 growth, ${ }^{118}$ the maximisation of consumer choice ${ }^{119}$ and not on sustainability, that is, lower consumption levels and organising the economy under conditions of slower economic growth. ${ }^{120}$

Accordingly, deep decarbonisation of the power system cannot take place in the current market environment without the revisiting and fundamentally revising the EU's various policies and the paradigm driving its market liberalisation and competition land state aid law regime since the 1990s. Sustainable consumption needs more state intervention and a lead in the shift from economic growth to slower economic growth and reduced consumption and production. ${ }^{121}$

The next section will turn to the Dutch legal and policy framework of the energy transition and which legal and policy measures have been taken so far to facilitate consumers in achieving sustainable energy markets.

\section{Dutch Energy Transition Law and Policy}

\subsection{Energy Transition Policy in the Netherlands} The Netherlands has gradually adopted a transition approach for sustainable energy, which is now one of the pillars of the overall government approach for climate change. ${ }^{122}$ However, Dutch energy policies concerning sustainability remained inconsistent until the country was faced with clear obligations to implement the binding sustainability targets of the EU Directives. This resulted in a volatile regulatory environment and had a negative impact on the investment climate regarding renewable energy generation. ${ }^{123}$ Until the adoption of the 2013 Energy Agreement, the Netherlands had no long-term energy and climate goals. ${ }^{124}$

More importantly, the Netherlands still pursues a strongly market- and competition-oriented energy policy. Competitiveness of the Dutch economy and improving the Dutch position on the international energy mar-

119. Consumer welfare is today a commonly accepted goal of competition laws. Consumers benefit from the process of competition through lower prices, better quality and a wider choice of new or improved goods and services. This is not different in EU Competition law where various soft law documents of the EU Commission confirm this principle. The CJEU stated in Post Danmark that one of the central parameters of competition is consumer choice. Case C-209/10 Post Danmark I, EU:C: 2012;172, para. 22.

120. Mont, above n. 11

121. Eyl-Mazzega and Mathieu, above n. 95

122. The transition approach officially started in 2002 with the project implementation transition management of the Ministry of Economic Affairs. With the action plan entitled 'More with energy. Chances for the Netherlands' the Dutch energy transition approach went 'public'. R. Kemp, 'The Dutch transition approach' 7 International Economics and Economic Policy 291, at 299-300 (2010).

123. E. Blokhuis, B. Advokaat \& W. Schaefer, 'Assessing the Performance of Dutch Local Energy Companies', 45 Energy Policy 680-90 (2012).

124. Akerboom and Van Tulder, above n. 43, at 334. It has also been emphasised that the lack of legislation obliging energy companies to produce power with RES as well as tax exemptions for large-scale energy consumption triggered a decrease of energy prices, contributed to energy inefficiency and impeded innovation in the field of renewables. 
kets are core policy goals of the energy transition as illustrated by its National Energy and Climate Plan for 2021-2030. ${ }^{125}$ This Plan builds on the Netherlands' overall aim to ensure a competitive electricity market, where consumers are able to optimally benefit from competition to make conscious choices and receive fair remuneration for investments in self-generation. Even its policy measures on consumer protection are strongly competition oriented as evidenced by its titles: 'policy and measures to protect consumers and to improve the competitiveness and competitive pressure of the energy market'. ${ }^{126}$ Institutionally, Dutch legislation on renewable energy is primarily drafted by the Ministry of Economic Affairs and Climate Policy and thus follows an economic rationale resulting in policies and subsidies aiming at large corporate projects with high profitability.

Despite the broad awareness of climate issues articulated by various sustainability initiatives that have been launched by citizens, businesses, NGOs and government agencies, ${ }^{127}$ the share of renewable energy remains the lowest among the twenty-eight EU countries, ${ }^{128}$ and thus the Netherlands is the furthest away from its renewable energy targets. ${ }^{129}$ A clear vision on the role of citizen initiatives in renewable energy and how to provide financial and other means of support is still absent in the Dutch energy and climate policy. ${ }^{130}$

\subsection{Dutch Energy (Transition) Policy Milestones} The Netherlands has undertaken many initiatives to achieve the targets set after the Paris Agreement and EU legislation. After concluding the Energy Agreement in $2013^{131}$ with various stakeholders and setting targets for reducing final energy consumption and increasing renewable energy production, ${ }^{132}$ a Climate Agreement has been reached in June 2019 and adopted by stakeholders and the Dutch government. ${ }^{133}$ Moreover, a

125. Integrated National Energy and Climate Plan 2021-2030, Netherlands, 2019.

126. Ibid., pp. 5, 30-33, 51.

127. Ibid., pp. 7, 11. https://ec.europa.eu/energy/sites/ener/files/ documents/nl_final_necp_main_en.pdf.

128. CBS, above n. 16

129. Renewable energy in the EU in 2018, Share of renewable energy in the EU up to $18.0 \%$, Twelve Member States have reached a share equal to or above their 2020 target, https://ec.europa.eu/eurostat/documents/ 2995521/10335438/8-23012020-AP-EN.pdf/ 292cf2e5-8870-4525-7ad7-188864ba0c29.

130. Akerboom and Van Tulder, above n. 43, at 334

131. Energieakkoord Voor Duurzame Groei, Sociaal-Economische Raad, Den Haag (2013), www.ser.nl/nl/thema/energie-en-duurzaamheid/ energieakkoord. Forty-seven organisations signed the 'Energy Agreement'. The signatories of the Agreement have a shared responsibility and commit themselves to achieve four goals (e.g. a $14 \%$ share of renewable energy in the Netherlands by 2020 , and a $16 \%$ share by 2023 , an average energy efficiency saving of $1.5 \%$ per year and creating at least 15,000 additional jobs by 2020 , compared to 2013 ).

132. www.government.nl/documents/publications/2013/09/06/energyagreement-for-sustainable-growth.

133. Klimaatakkord, Den Haag, 28 Juni 2019. www.rijksoverheid.nl/ onderwerpen/klimaatverandering/documenten/rapporten/ 2019/06/28/klimaatakkoord. framework law, the Climate Act, ${ }^{134}$ has been adopted by the Dutch Parliament as of May 2019. The 2013 Energy Agreement, 'Agreement for Sustainable Growth', was signed by the Dutch government and civil society representatives ${ }^{135}$ and comprised a set of voluntary agreements expressing joint intention of various stakeholders to make the energy supply system more sustainable. The Agreement underlined the relevance of decentral generation of renewable energy sources and included among others the objective to increase the share of renewable energy generation (over 4\% in 2013) to $14 \%$ in 2020.136 The Agreement acknowledged that the Dutch legal framework failed to support new organisational forms and new actors who engage in distributed generation of renewables ${ }^{137}$ and introduced a specific financial incentive, the so-called 'postal code subsidy'. It also underlined the need to make consumers aware of energy efficiency measures they can take themselves. ${ }^{138}$ Still, most of these measures are aimed at larger companies and investors and the current subsidy system rewards projects with the highest potential, based on their economic viability and undermined initiatives at the local level. The Agreement had a modest focus on decentralisation and inclusion of local citizens-driven projects with typically modest revenue models and that fit much less into this policy. ${ }^{139}$

Following the Energy Agreement, the 2017 Coalition Agreement of the Dutch government presented an ambitious energy policy with the aim to achieve a $49 \%$ reduction in greenhouse gas emissions by 2030 (compared to 1990) and a $95-100 \%$ reduction by $2050 .{ }^{140}$ One of the commitments of the 2017 Coalition

134. The Climate Act came into force in the Netherlands on 1 September 2019. The aim of this act is to reduce emissions of greenhouse gases, such as CO2. Excessive greenhouse gas in the atmosphere changes the climate and has negative consequences for people and the natural environment. Klimaatwet, Wet van 2 juli 2019, houdende een kader voor het ontwikkelen van beleid gericht op onomkeerbaar en stapsgewijs terugdringen van de Nederlandse emissies van broeikasgassen teneinde wereldwijde opwarming van de aarde en de verandering van het klimaat te beperken.

135. Energieakkoord Voor Duurzame Groei, above n. 131, www.ser.nl/-/ media/ser/downloads/overige-publicaties/2013/energieakkoordduurzame-groei.pdf? $l a=n l \& h a s h=9004 D 9 A 04580$ C40E7E0F17E15A38C634

136. Energieakkoord Voor Duurzame Groei, above n. 131, pp. 79-83.

137. Therefore, the Agreement stated that the legal framework of the electricity sector had to facilitate innovation, in the form of legal space for enabling new developments, such as decentral generation of RES. Energieakkoord Voor Duurzame Groei, above n. 131, pp. 83-85.

138. Energieakkoord Voor Duurzame Groei, above n. 131, pp. 39-44.

139. M. Oteman, M. Wiering \& J.-K. Helderman, 'The Institutional Space of Community Initiatives for Renewable Energy: A Comparative Case Study of the Netherlands, Germany and Denmark', 4 Energy, Sustainability and Society 11 (2014). It focuses on the economic attainability of the energy transition and smart investments in large-scale generation. M. Oteman, H.-J. Kooij \& M.-A. Wiering, 'Pioneering Renewable Energy in an Economic Energy Policy System: The History and Development of Dutch Grassroots Initiatives', 9 Sustainability 550 (2017).

140. Confidence in the Future, 2017-2021 Coalition Agreement, People's Party for Freedom and Democracy (VVD), Christian Democratic Alliance (CDA), Democrats '66 (D66) and Christian Union (CU), www.government.nl/documents/publications/2017/10/10/coalitionagreement-confidence-in-the-future, p. 41. See also Integrated National Climate and Energy Plan, The Netherlands, 2021-2030. https:// 
Agreement was the realisation of a Climate Agreement, which was presented in June 2019. ${ }^{141}$ The Climate Agreement set out in detail how the Netherlands plans to achieve its $\mathrm{CO} 2$ emission reduction objectives and defines policies and measures to support the achievement of the emissions reduction targets. ${ }^{142}$ The Agreement was developed through a collaborative process involving parties from across Dutch society with hundreds of organisations, companies and governmental authorities and provided for governmental action in five different areas such as electricity; transport; agriculture and land use; industry; and built environment. The Climate Agreement is an essential part of the Climate Plan, and of the National Energy and Climate Plan (NECP) that member states of the $\mathrm{EU}$ are required to submit to the European Commission.

Moreover, on 1 September 2019, the Dutch Climate $\mathrm{Act}^{143}$ came into force, making the Netherlands the seventh country in the world to have a Climate Act. The Act requires the Dutch government to draw up a Climate Plan setting out measures to ensure that the targets as defined in the Act will be achieved. The Climate Act also contains a policy framework for achieving the climate objectives of the Dutch government and provides three policy instruments: a five-yearly Climate Plan, a two-yearly Progress Report and an annual Climate Memorandum. ${ }^{144}$

Despite these developments, the 2020 Report of the Advisory Division of the Netherlands' Council of State on the first Climate Memorandum of the Dutch government stressed that the 'climate goals written into Dutch law are not being met'. ${ }^{145}$ A forecasted reduction of 34\% in relation to 1990 levels falls short of the Climate Act's

ec.europa.eu/energy/sites/ener/files/documents/

nl_final_necp_main_en.pdf.

141. www.klimaatakkoord.nl/elektriciteit.

142. One of the measures was a legislative proposal introducing a minimum price on CO2 which was intended to take effect as of 1 January 2020. However, the process has been delayed and the proposal is still being debated by the Dutch Parliament.

143. Klimaatwet, Wet van 2 juli 2019, Kamerstukken 34534, nr. 3, Vergaderjaar 2018-2019. Staatsblad 2019, 253.

144. The government must draft a Climate Plan every five years, containing the main elements of the climate policy for the next ten years. Each year the minister of Economic Affairs and Climate sends a Climate Memorandum to the senate and the house of representatives. This memo contains the minister's response to the annual report from the Netherlands Environmental Assessment Agency (the climate and energy investigation) regarding the progress of the climate policy. Every two years after the Climate Plan, a Progress Report is published, which may contain supplementary policy in order to achieve the goals established in the Climate Act. The Advisory Division reviews whether the government can achieve the climate goals set out in the Climate Act with the Climate Plan, Climate Memorandum and Progress Report.

145. 'An analysis by the Netherlands Environmental Assessment Agency (PBL) of the climate policy contained in the government's 'Climate and Energy Study 2020' (KEV) sees negligible results and little observable progress.' The Council of State urged the adoption of new policies and that existing legislation and practical realisation is more strongly aligned in order to achieve greater impact. An effective, coherent and coordinated legislative programme is urgently needed. Raad van State, Report of the Advisory Division of the Council of State on the first Climate Memorandum of the Dutch government, 1 October 2020, W18.19.0301. objective of $49 \%$ by 2030 , while the ultimate goal of $95 \%$ reduction by 2050 is beyond reach. ${ }^{146}$

The Netherlands' climate and energy policy has also been significantly influenced by the climate case Urgen$d a .{ }^{147}$ The case has been lodged against the Dutch government in 2015 and it is the first case around the world where citizens claim that their government has a legal obligation to prevent climate change. On appeal, the Hague Court of Appeal and the Dutch Supreme Court confirmed the first instance ruling of the District Court of The Hague ordering the Netherlands to reduce its emissions by a minimum of $25 \%$ before 2020 compared to the 1990 levels. The Dutch renewable energy goals had to be more aspiring as a result of this successful liability case. ${ }^{148}$

The latest development in Dutch energy policy is marked by the Proposal to amend and replace the Dutch Gas and Electricity Act which was published in December $2020 .{ }^{149}$

It focuses on sustainability and energy transition and a strengthened role for the end-consumer concerning sustainable energy consumption and self-generation of electricity. ${ }^{150}$ The Proposal introduces important changes concerning the definition of the various categories of energy consumers. The current Dutch electricity legislation does not define household consumers, but distinguishes small consumers (kleinverbruikers) from large consumers on the basis of the size of the connection to the electricity network. In line with the current definitions in Article 2 (4) and (6) of Directive 2019/944 concerning household customers and micro-enterprises, ${ }^{151}$ the Proposal also introduces micro-enterprises and provides the same level of protection to microenterprises as for end-consumers. ${ }^{152}$

146. Report Climate Memorandum 2020, www.raadvanstate.nl/climate/An updated estimate of emissions reductions covering the impact of all of the Climate Agreement's measures as well as additional measures implemented in 2019 and 2020 was published in October 2020. IEA, The Netherlands 2020 (2020). www.iea.org/reports/thenetherlands-2020.

147. Climate case Urgenda, ECLI:NL:GHDHA:2018:2610.

148. Ibid., paras. 74-75.

149. It is now under public consultation. Conceptvoorstel van wet houdende regels over energiemarkten en energiesystemen (Energiewet), CONCEPTVOORSTEL VAN WET (versie internetconsultatie 17 december 2020), Memorie van toelichting wetsvoorstel Energiewet, publieke versie 17 december, both available: www.internetconsultatie.nl/ energiewet.

150. Memorie van toelichting wetsvoorstel Energiewet, pubieke versie 17 december, pp. 4, 7-8. See Pillars IV and V of the Concept Act, p. 5.

151. Users with a connection smaller than a maximum of $3 * 80$ Ampere are small consumers and those with a larger connection are defined as large consumers. Households and most small businesses have a connection that is equal or smaller than this size and enjoy special protection under the Electricity Act. The protection of small end-users is one of the main objectives of the Electricity Act. Art. 95a chapter $8 \S 1$ of the Electricity Act defines the small consumers as consumers with a maximum connection size of $3 * 80$ A. Kamerstukken II. 2007-08, 31374, nr. 2 and 3. Art. 95a of the Dutch Electricity Act, Besluit van 14 februari 2006, houdende regels inzake voorzieningen in verband met de leveringszekerheid (Besluit leveringszekerheid Elektriciteitswet 1998).

152. Memorie van toelichting wetsvoorstel Energiewet, publieke versie 17 december, Section 3.6 A, p. 56. 
The Proposal implements all the rules as laid down in Directive 2019/944 concerning the increased protection of final consumers (Arts. 4, 10-14, 26) as well as legal measures to activate consumers to participate in demand response, self-generation, self-consumption of energy and local energy communities (Arts. 15-19).

In sum, the Dutch energy transition policy is ambitious, but is relatively of young origin and so far lacks a clear focus on (strong) sustainability and consumers' participation.

\subsection{Consumers' Role and Legal Position in Dutch Energy Transition}

The Dutch legal framework of energy is primarily based on EU Directives that were implemented by the Dutch Electricity Act of 1998, which is the main source of energy regulation in the Netherlands. The current law presumes a passive role of the consumer, the household end-user with emphasis on security of supply and affordability. A broad legal implementation of renewable energy production has not yet taken place, and while technology measures such as the roll-out of the smart metres could potentially contribute to community supply, administrative and financial barriers persist. ${ }^{153}$

According to Article 95 of the Dutch Electricity Act 1998, household consumers cannot produce or sell electricity without a licence. In theory it is possible for consumers to get a licence, but in practice individual consumers are unlikely to obtain a licence due to their inability to comply with the legal requirements of organisational, financial and technical characteristics of a good performance of their tasks as energy suppliers ${ }^{154}$ and the obligation to provide universal services that all energy suppliers in the Dutch market have to fulfil. ${ }^{155}$ Moreover, most consumers are not able to consume energy at the moment they produce it and thus engaging in electricity generation does not necessarily enable small consumers to be self-sufficient. Even though they might generate the same amount they consume, usually the intermittent character of renewable energy does not coincide with the main consumption periods. There could be a technical solution to this problem in the form of storage facilities, for example, home batteries could capture excess electricity for later consumption. Storage has not been applied on a large scale so far and thus, administrative solutions of feed-in tariffs and net metering schemes are employed ${ }^{156}$ that will be analysed in the next sections.

\subsubsection{Support Schemes}

Compelled by the EU Renewables Directive obligation, the Netherlands has introduced various legal provisions

153. Akerboom and Van Tulder, above n. 43

154. Art. 95 d. 1 of the Dutch Electricity Act 1998

155. Ibid.

156. This leaves consumers who start generating electricity (individually or collectively) dependent on electricity supply by an energy supply company. These small consumers who also produce electricity are often referred to as 'prosumers'. L. Diestelmeier and D. Kuiken, 'Legal Framework for Prosumers in the Netherlands', in M. Roggenkamp and C. Banet (eds.), European Energy Law Report XII (2018) 151-68. aiming at incentivising the generation of renewable energy sources.

So far, the production of renewable energy is mainly supported by a subsidy scheme, which is a feed-in-tariff for producers of renewable energy to compensate them for the non-profitable portion of the costs of renewable energy. This scheme - established by the Decree on the stimulation of sustainable energy production (SDE Decree $)^{157}$ - provides financial compensation for the generation of renewable energy. ${ }^{158}$ However, the programme's focus switched from small-scale to industrialscale renewable energy production in order to speed up technological development and assist with reaching the renewables targets. Therefore, it is a scheme for companies and not-for-profit organisations (e.g. cooperatives) and remains of limited relevance for consumers. ${ }^{159}$

However, there are two main support schemes in place that incentivise consumers to engage in electricity generation: net metering and the 'postal code' subsidy. These provisions either incentivise individual (small) consumers or groups of consumers (communities) to produce renewable energy.

\subsection{Net Metering}

The current Dutch regulatory framework does not contain any specific provisions relating to energy storage and therefore does not specifically support the investment in storage solutions. However, under Dutch law consumers have the possibility to use a net metering scheme that allows consumers to offset an energy surplus of their power production, which will be fed into the grid, with the electricity that they consume from the electricity supplier. ${ }^{160}$ Consumers are exempted from the payment of the sustainable energy surcharge and energy taxes.

For private electricity prosumers, who mainly produce solar energy on their rooftops, energy-related taxes only apply to their net electricity consumption over a yearly period. Grid operators have to provide a contract to producers feeding electricity to the grid. The net metering system enables consumers to pay only for the elec-

157. Stimulering Duurzame Energieproductie, https://english.rvo.nl/ subsidies-programmes/sde.

158. Production of renewable energy is not always profitable because the cost price of renewable energy is higher than the market price. The difference in price is called the unprofitable component. SDE+ compensates producers for this unprofitable component for a fixed number of years, depending on the technology used.

159. https://english.rvo.nl/subsidies-programmes/sde; Study on 'Residential Prosumers in the European Energy Union', JUST/2015/CONS/FW/ C006/0127, 2017, at 48. Financial support measures led, for example, to the implementation of large-scale on- and off-shore wind turbines, but also to small-scale generation such as photovoltaic (PV) installations on residential houses. PV installations can be integrated by individual small consumers on their own grounds and wind turbines or PV parks can also be installed collectively by small consumers beyond their own premises. In this way, small consumers can engage in electricity generation and gain subsequent financial benefits. Diestelmeier and Kuiken, above n. 156

160. The net metering scheme will be replaced in 2023 by a new support mechanism, the feed-in subsidy, which can be defined as compensation for the electricity which has been fed back into the grid. Power generation in the Netherlands, www.lexology.com/library/detail.aspx? $g=40 a 4 e 593-5 c 1 d-4 c f e-96 b 5-e d 4 c f 0 e 88 e a 4$. 
tricity they consume, including taxes. The energy bill indicates how much energy the consumer has produced and how much energy the supplier has delivered. The difference is the net consumed which the supplier will invoice for. Participation in the net metering system is conditioned on that the electricity has to be supplied and fed into the same connection and that the consumer can be qualified as small user, with a connection of maximum $3 * 80$ Ampere. ${ }^{161}$

Thus, the net metering scheme only applies to network users with a low-volume connection and, in principle, to electric power which is consumed and delivered via the same connection. Net metering aims to stimulate selfgeneration of consumers at the level of self-sufficiency, but it is not lenient towards generation above this level. Its drawback is that consumers are not encouraged to invest in energy storage as the whole surplus can be set off. While the net metering scheme may increase support for energy transition among consumers who make use of the scheme, it may decrease support among other consumers who do not benefit from it but, as a matter of fact, are faced with higher taxes. ${ }^{162}$ The net metering scheme will gradually be phased out from 2023 to 2030 and replaced by a new subsidy regime.

\subsection{Postal Code Area Regulation}

As the net metering scheme does not accommodate prosumers operating the generation of renewable energy collectively, the 2013 Energy Agreement introduced a specific financial incentive, the so-called 'postal code regulation' in the form of a subsidy.

As mentioned above, Dutch legislation prohibits 'selfconsumption' of the electricity produced. The postal code area regulation is an exception to this rule. The amount of electricity generated by the consumer which can be offset is subjected to the offset limit, which is determined by the amount of own consumption. A feedin tariff, determined by the supplier, applies to generation which exceeds this limit. It is a tax arrangement by the government which exempts participants in a cooperative project to generate renewable energy from having to pay energy tax. ${ }^{163}$ This regulation provides energy tax relief to private consumers organised in a cooperative or homeowner association, who produce electricity up to the amount they consume yearly, on another rooftop than their own. The most salient constraint of this arrangement relates to the spatial area for which the tax relief applies: the postal code area where the installation

161. Study on 'Residential Prosumers in the European Energy Union', JUST/ 2015/CONS/FW/C006/0127, 2017, p. 54.

162. M. Mulder, 'Energy Transition and the Electricity Market: An Exploration of an Electrifying Relationship', University of Groningen March 2017, Groningen, p. 23

163. It is, however, conditional upon the requirement that the production installation owned and operated by the collective is located within the same or directly adjacent postcode area where the consuming member of the collective lives. Moreover, the limitation of maximum own consumption (self-sufficiency level of $\max 10,000 \mathrm{kWh} /$ year) is also applicable to this scheme, similarly to the net metering arrangement available to individual prosumers. A. Butenko, 'Sharing energy: dealing with regulatory disconnection in Dutch energy Law' 7 European Journal of Risk Regulation, (2016) 712. (a solar roof) is situated, together with all adjacent postal code areas. ${ }^{164}$

\subsection{Energy Communities}

EU law provides for the first time an enabling legal framework for collective citizen participation in the energy system by defining 'citizen energy communities' in Directive 2019/944, and 'renewable energy communities' which is included in the revised Renewable Energy Directive 2018/2001.

Energy communities are new types of non-commercial entities that, although they engage in an economic activity, their primary purpose is to provide environmental, economic or social community benefits rather than prioritise profit making.

Energy communities are contiguous processes of the energy transition and as decentralised and renewablebased energy projects, they can promote sustainable energy production and consumption practices. As consumer-empowerment and community-driven initiatives, energy communities can play a key role for social innovation as they reflect a fundamental shift in consumer behaviour.

In 2015 the Dutch government adopted a Decree for experiments with decentralised renewable electricity generation. ${ }^{165}$ The Experimentation Decree entails the temporary testing of a unique legal approach and aims to gain insights on how to adjust the legal framework. ${ }^{166}$ The Experimentation Decree aims at investigating how experiments could contribute to distributed generation, to promote the efficient use of the energy infrastructure and also to improve consumers' involvement. To do so, the Decree allows for certain exemptions from the Electricity Act's provisions that support the energy transition among others, though increasing the involvement of energy users in their own energy provision. ${ }^{167}$ Only projects operated by cooperatives and associations of owners are eligible for permission and $80 \%$ must be end-consumers. The community energy associations

164. Proka, Hisschemöller \& Loorbach, above n. 34, at 7.

165. Ministerie van Economische Zaken. Besluit van 28 Februari 2015, Houdende Het bij Wege van Experiment Afwijken van de Elektriciteitswet 1998 voor Decentrale Opwekking van Duurzame Elektriciteit; Ministerie van Economische Zaken: Den Haag, The Netherlands, 2015.

166. In general, experimental legislation is a form of temporary regulation with a well-defined scope that may derogate from existing laws or standards. They are designed in order to test 'novel legal approaches or to regulate new products or services so as to gather more information about them'. S. Ranchordás, Constitutional Sunsets and Experimental Legislation: A Comparative Perspective (Elgar Monographs in Constitutional and Administrative Law) (2014); I. Lammers and L. Diestelmeier, 'Experimenting with Law and Governance for Decentralized Electricity Systems: Adjusting Regulation to Reality?', 9(2) Sustainability 212 (2017)

167. Other purposes are Experimentation Decree allows experiments for the purpose of (1) increased utilisation of renewable energy or combined heat and power (CHP) at local level; (2) more efficient use of the available energy infrastructure; (3) increased involvement of energy users in their own energy provision. Ministerie van Economische Zaken. Besluit van 28 Februari 2015, Houdende Het bij Wege van Experiment Afwijken van de Elektriciteitswet 1998 voor Decentrale Opwekking van Duurzame Elektriciteit; Ministerie van Economische Zaken: Den Haag, The Netherlands, 2015. 
and cooperatives can organise energy sharing and set their own internal tariffs for supply.

The Decree enables associations to engage in peer-topeer electricity supply and thus any domestic customer generating electricity can supply electricity to other domestic customers without having to acquire a licence as Article 95a of the Dutch Electricity Act prescribes. As mentioned above, because of the licence consumers are restricted in selling their surplus electricity on the market, which in turn prevents consumers to fulfil their active role in the electricity market. The Decree's scope is limited to local sustainable energy collectives, associations who carry out all tasks in the electricity supply chain and engage in collective generation, peer-to-peer supply and system operation.

In this way, traditionally passive consumers are becoming an energy prosumer, co-owner of renewable energy facilities and community energy participant. Currently, there are 623 community energy initiatives in the Netherlands. ${ }^{168}$ The above-mentioned recent policy developments such as the Energy Agreement create more legitimacy for this collaborative action. The proposed new Electricity Act aligns with EU law and introduces both the definition and provisions to support the energy communities as active contributors to the energy transition, ${ }^{169}$ With this it acknowledges the indispensable role energy cooperatives play in the transition and that this societal role is increasingly recognised by the Dutch government.

However, as energy communities today still play a marginal role in the energy sector, further Dutch legislation and policy-making needs to give increased support to realise their full potential. The discrepancy remains between the facilitating legal rules and the overall policy framework where the focus is still on large energy companies $^{170}$ and articulating economic rationales. Moreover, a deeper understanding of consumers' motivations to engage in energy communities needs to be explored and further laws and policies designed on the basis of these social practices that underlie them.

\section{Conclusions}

Energy transition is a complex environmental problem and a multifaceted process that is more comprehensive than just a change in the energy consumption. It touches upon current societies' socio-economic structures and requires fundamental changes in the existing energy systems' institutions, formal and informal rules and the behaviour of its actors. The role of consumers in this

168. Hieropgewekt, Local Energy Monitor, 2020. www.hieropgewekt.nl/ lokale-energie-monitor.

169. Memorie van Toelichting, pp. 62, 66, and 70 .

170. The energy mix is based largely on fossil fuels (e.g. $80 \%$ of Dutch electricity is generated from fossil fuels; Enerdata, 2019) and the sector is dominated by three large energy companies, two of which have been acquired by foreign companies. A. Vernay and C. Sebi, 'Energy Communities and Their Ecosystems: A Comparison of France and the Netherlands', 158 Technological Forecasting and Social Change (2020). process has been distinct, but at the same time complex in legal, social and economic terms. In law and policy consumers are considered as the real drivers of the energy transition who can participate in decentralised renewable energy production. In this way, consumers can become fully involved in the energy system and effectively have the power to steer the energy transition towards sustainability.

However, so far progress in the energy transition has been too limited and studies show that consumers remain disengaged. Studies show that consumers may only think about their energy consumption and use for nine minutes a year, probably when it is time to pay their bills. ${ }^{171}$ Sustainability policy strategies overemphasise personal responsibility and reduce responsibility of other organisations or institutions. ${ }^{172}$ Current energy policies rely heavily on a governance approach that manifestly shifts responsibility from states to consumers to make responsible choices for more renewable energy. For example, the EU's Green Deal underlines the role of consumers in the clean energy transition ${ }^{173}$ and the most recent Consumer Agenda of the EU emphasises that consumers' energy choices are key to deliver on the climate change targets for 2030 and climate neutrality by 2050.

Such a responsibilisation of consumers calls on consumers' socially responsible choices to steer towards sustainability. However, such a conceptualisation of social consumer responsibility is absent in both EU and Dutch law. They rely heavily on economic rationale and corresponding information tools and place consumer choice at the heart of the internal market, energy law and various other legal fields. It has been argued above that sustainable consumption approach requires a shift from information provisions and behavioural nudges to more systematic understanding and addressing of social practices that are at the root cause of energy use. Consumer responsibility could be constructed and conceptualised by relying more on political theories of citizenship and endorsing the side of civic duties.

The fundamental revision of EU and Dutch law towards more facilitative legal framework both for individual and collective consumer participation is a welcome development. Most notably, the Experimentation Decree in the Netherlands offers a promising legal instrument to promote decentralised, sustainable energy while contributing to citizens' participation in an energy community. Yet, they crucially remain embedded in a broader legal and policy framework that is still focusing on competitiveness, increased consumer choice and economic growth. Consumers remain embedded in political and legal arrangements that addressed them as sovereign consumers who have the power and capacity to make rational choices that drive the change to sustainability. However, such insulated legal and policy

\footnotetext{
171. https://marinecornelis.medium.com/can-we-put-smart-meters-at-theservice-of-users-cceea23c577b

172. Luchs, Phipps \& Hill, above n. 86, at 1463.

173. The European Green Deal, $\operatorname{COM}(2019) 640$ final, p. 6.
} 
changes remain ineffective and that we need to engage in broader the change in energy systems has to take place by influencing the social practices energy use is built on. 